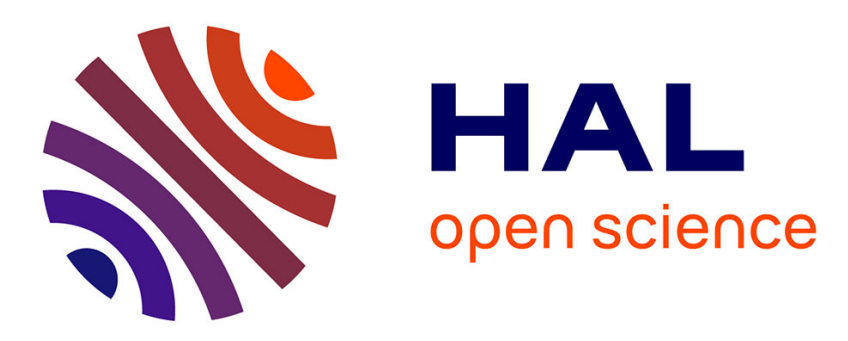

\title{
Cinderella purchasing transformation: linking purchasing status to purchasing practices and business performance
}

Davide Luzzini, Stefano Ronchi

\section{- To cite this version:}

Davide Luzzini, Stefano Ronchi. Cinderella purchasing transformation: linking purchasing status to purchasing practices and business performance. Production Planning and Control, 2016, 27 (10), pp.787-796. 10.1080/09537287.2015.1137986 . hal-01289902

\section{HAL Id: hal-01289902}

https://hal-audencia.archives-ouvertes.fr/hal-01289902

Submitted on 17 Mar 2016

HAL is a multi-disciplinary open access archive for the deposit and dissemination of scientific research documents, whether they are published or not. The documents may come from teaching and research institutions in France or abroad, or from public or private research centers.
L'archive ouverte pluridisciplinaire HAL, est destinée au dépôt et à la diffusion de documents scientifiques de niveau recherche, publiés ou non, émanant des établissements d'enseignement et de recherche français ou étrangers, des laboratoires publics ou privés. 


\section{Cinderella purchasing transformation: linking purchasing status to purchasing practices and business performance}

Authors: Davide Luzzini, Stefano Ronchi

Journal: Production Planning \& Control

Link to final version:

http://www.tandfonline.com/doi/abs/10.1080/09537287.2015.1137986 


\title{
Cinderella purchasing transformation \\ Linking purchasing status to purchasing practices and business performance
}

\author{
Davide Luzzini*1 ${ }^{1}$, Stefano Ronchi ${ }^{2}$ \\ * Corresponding author: dluzzini@audencia.com \\ ${ }^{1}$ Audencia Business School \\ 8 route de la Jonelière, 44312 Nantes, France \\ ${ }^{2}$ Politecnico di Milano \\ School of Management \\ Piazza Leonardo da Vinci 32, 20133 Milano, Italy
}

\begin{abstract}
This paper contributes to the on-going debate about the relevance of the purchasing function for the firm value creation. We empirically examine the role of the purchasing function in improving business performance through an international survey based on 653 responses. Results suggest that purchasing practices related to spend rationalization have a positive impact on the overall business performance, whereas supplier development \& integration and sustainable purchasing have not. Moreover, the purchasing recognition by top managers and other organizational units emerge as a powerful antecedent of all purchasing practices. Instead, pure formal authority provided by the position in the organization chart (i.e. the report level) does not have any influence on purchasing practices adoption.
\end{abstract}

Keywords: Purchasing Status, Purchasing Practices, Business Performance

\section{Introduction}

In recent decades, a long and stimulating debate has been developed in the Purchasing and Supply Management (PSM) literature about the role of purchasing within companies (Carr \& Pearson, 1999; Chen et al., 2004; Mehra and Inman, 2004; Ogden et al., 2007; Bernardes \& Zsidisin, 2008). There is no doubt that purchasing activities have acquired a substantial weight over time due to the increasing rate of outsourcing decisions. As a matter of fact, purchasing spend has increased in the last fifteen years and nowadays it might be up to $80 \%$ of total company's budget (Perkins and Gunasekaran, 1998; Wagner, 2006; Ramsay \& Croom, 2008). Even if this figure seems self-explanatory, the actual role of the purchasing function is still under discussion as researchers and practitioners do not always share the same views (Ramsay, 2001; Mol, 2003; Cousins, 2005). Purchasing is often considered by many practitioners as a "Cinderella" department necessary for the company, but not strategic for its success (Carter \& Narasimhan, 1996; Cox \& Lamming, 1997; Ramsay \& Croom, 2008). Other organizational units (e.g., Marketing and Sales, Finance and Control) are perceived as more strategic in order to improve business performance.

In the academic literature, scholars have been trying to define and assess the role of the purchasing function in several ways: by looking at the activities it performs, either clerical or strategic (Ramsay, 2001); by considering its engagement with the top management (Cousins et al., 2006); or by measuring its impact on the overall business 
performance (Bernardes \& Zsidisin, 2008; Najmi and Makui, 2011; Hartmann et al., 2012). However, other authors do not share the same views (e.g., Mol, 2003; Rozemeijer, 2008). As a result, a common conclusion is missing, thus creating a potential gap in the literature: some scholars argue that purchasing activities are crucial for a company's success, while others question the strategic role of purchasing.

This debate is further complicated by the fact that the actual ability of purchasing employees to affect business performance through the implementation of specific purchasing practices likely depends upon the formal authority assigned to purchasing as well as the recognition of peer departments. Even though few studies partially take these factors into account (e.g., Knoppen \& Saenz, 2014), there is still much to learn about the antecedents of purchasing practices adoption.

This paper contributes to the discussion by investigating two main research questions:

- Do purchasing practices have an actual impact on business performance?

- Does purchasing recognition (both informal and formal) enable the adoption of purchasing practices?

The paper is structured in seven sections. After this brief introduction, an overview of the studies considering the role of the purchasing function, its contribution to business performance, and its status is provided. The third section presents the research framework and the hypotheses, followed by the methodology used. The fifth section illustrates data analysis, and the sixth section provides the interpretations of results. Finally, the last section reports concluding remarks, research limitations and possible future developments.

\section{The role of the Purchasing Function}

Despite, since the 1980s, some early contributions tried to show how the purchasing function could be considered as strategic and could contribute to the competitive advantage of a firm (Kraljic, 1983; Porter, 1985; Burt \& Soukup, 1985), more recently some doubts about the relevance of purchasing have arisen. Many examples show that purchasing and supply management play a strategic role for companies, but at least the same number of cases suggest that those functions are not considered strategic at all (Nelson et al., 2001). A number of studies prove that there is no common view about this issue. For example, Ramsay (2001a) argues that purchasing is "irrelevant", grounding on the Resource-Based View (RBV) of the firm: since companies tend to outsource their non-core competences, anything purchased externally cannot be a source of competitive advantage. Similarly, Ellram et al. (2002) do not find a significant relationship between purchasing and supply activities and the return to shareholders, and envisage future research implementing broader definitions of business performance. However, Ramsay himself (2001b) criticises the RBV perspective, by stating that not all purchasing functions are the same, companies do not always have the same information, and imitation costs might be very high. Therefore, there might be space for outsourced activities to create a competitive advantage. Furthermore, Mol (2003) questions Ramsay's initial argument by adopting RBV's more recent developments as well as other strategic management theories, suggesting that external resources can generate competitive advantage and therefore purchasing might play a strategic role within organisations as the primary interface with suppliers.

Later studies explore such role, especially focusing on the activities the purchasing function is responsible for, usually distinguishing strategic from operational/clerical activities. Ramsay \& Croom (2008) acknowledge this distinction, but argue that there is 
no one-size-fits-all classification: whether one task is strategic or not depends on many contingent factors (e.g., the industry or the business strategy). Moreover, both strategic and operational activities can be a source of competitive advantage. For this reason, the authors criticise one-way evolutionary models prescribing that the purchasing function should ultimately aim at strategic tasks. Instead, Rozemeijer (2008) reject any distinction between strategic and clerical activities, since any task carried on within a functional unit is important. Moreover, he stresses the relevance of purchasing development models for the professions and the need for careful empirical testing.

More recent studies carry on this debate and confirm that purchasing can have an impact on business performance. Hartmann et al. (2012) show the positive effect of purchasing maturity (conceived as a set of practices) on the firm's operational and financial performance. Zimmerman and Foerstl (2014) conduct a meta-analysis that provides strong support for the purchasing practices-performance link, from the perspective of the buying firm. The authors offer suggestions for future research, including the need for a more nuanced view of the different practices that can affect the different types of performance considered (for example, market performance seems relatively under-investigated). On the one hand, these studies confirm that the role of the purchasing function should be analysed in light of its actual contribution to business performance. On the other hand, we argue that the role of the purchasing function cannot be assessed by simply looking at the activities it is in charge of, but also at its status within the firm, and research is needed to identify concrete measures for the status of this function independently of the assigned tasks.

The next section follows up these considerations and presents our theoretical model. We develop specific research hypotheses regarding, firstly, purchasing practices that are expected to improve business performance; and, secondly, the driving role played by the purchasing status (both informal and formal).

\section{Research framework and hypotheses}

\subsection{Purchasing Function's contribution to Business Performance}

The examination of prior research suggests that the relevance of purchasing is driven by the contribution to overall business performance. Carter \& Narasimhan (1996) conduct one of the first relevant studies, linking six purchasing practices (i.e., the importance of purchasing, human resources management, interaction with suppliers, influence over suppliers, interaction with other departments, purchasing organisation and structure) to sales and marketing performance, without considering profit-related performance or any control variable. More recently, other studies analyse the link between the purchasing function and business performance (Carr \& Pearson, 1999; Narasimhan \& Das, 2001; Paulraj et al., 2006; González-Benito, 2010), even including financial performances, such as ROI and net profit (Moody, 2001; Chen et al., 2004; Oltra \& Flor, 2010; Hartmann et al., 2012). Some contributions specifically focus on the role of purchasing and suppliers' involvement in new product development, especially when companies pursue a differentiation strategy (Carr \& Pearson, 2002; Cousins, 2005; Azadegan \& Dooley, 2010; Wynstra et al., 2010; Oke \& Kach, 2012; Luzzini et al., 2015).

Across all these studies, three major approaches may be identified. The first approach investigates the relationship between operational competitive priorities and business performance (e.g., González-Benito, 2010; Oltra \& Flor, 2010). The second approach highlights the link between the functional-business strategy alignment and business performance (e.g., Cousins, 2005; González-Benito, 2007). Finally, the third approach investigates the relation among initiatives, managerial levers and practices 
undertaken at the functional level and business performance (e.g., Ellram et al., 2002; Azadegan \& Dooley, 2010; Wynstra et al., 2010). We adopt the third approach and consider three major sets of purchasing practices that are expected to affect the overall business performance. In particular, we take into consideration recent recommendations to include both external practices accounting for the relationship management with suppliers as well as internal practices accounting for the skills and capabilities of the purchasing function (e.g., Zimmermann \& Foerstl, 2014). In addition to that, we include a general set of practices that acquired relevance in recent years as a consequence of sustainability becoming a key objective for firms (McKinsey, 2014) and for purchasing (Blome et al. 2014; Caniato et al. 2014; Marshall et al., 2015). Table II and III summarize the constructs considered in our theoretical model and their operationalization respectively.

The first cluster of purchasing practices includes Supplier Development \& Integration practices, assuming that collaboration with suppliers might improve business performance (De Toni \& Nassimbeni, 2000; Narasimhan \& Das, 2001; Ellram et al., 2002; Hartmann et al., 2012). In particular, technological collaboration in terms of technology sharing, joint new product development and requirements alignment, and operational collaboration in terms of sharing planning and forecasts and order management systems are considered (Cousins, 2005; Humphreys et al., 2011; Buyukozkan \& Arsenyan, 2012). The second cluster takes into consideration one of the most common task for purchasing, i.e., Spend Rationalization. In particular, supply base optimization in identifying the appropriate number of suppliers and the sourcing strategy (Berger et al., 2004; Yu et al., 2009) together with the degree of purchasing centralization (Arnold, 1999) are analysed. In addition, a clear portfolio management strategy is considered as a sign of purchasing maturity as well as the necessary premise for spend rationalization (Gelderman \& van Weele, 2005). Finally, Sustainable Purchasing practices are also included in the study. That means for example recycling and packaging waste reduction initiatives, vendor assessment on environmental and social performance, and social compliance programs (Bowen et al., 2001; Carter, 2004; Rao \& Holt, 2005; Walker \& Phillips, 2009).

Based on such premises, we can introduce our first research hypothesis:

\section{H1: Purchasing Practices have a positive effect on Business Performance. \\ H1a: $\quad$ Supplier Development \& Integration has a positive effect on Business Performance. \\ Hlb: $\quad$ Spend Rationalization has a positive effect on Business Performance. \\ H1c: $\quad$ Sustainable Purchasing has a positive effect on Business Performance.}

\subsection{Status of the Purchasing Function}

There is a general consensus that increasing the automation (Caniato et al., 2012) and outsourcing (Brewer et al., 2014) of purchasing activities leads to a reconfiguration of purchasing roles and responsibilities, which are becoming less operational and more strategic. However, evidence about purchasing position in the organisational hierarchy and its status relative to other functions is still equivocal (Zheng et al., 2007). For example, Johnson et al. (1998) reveal that Chief Purchasing Officers (CPOs) mostly have an operations/production background and that purchasing responsibilities in the make-or-buy decisions were less than expected. Pearson et al. (1996) find that the purchasing status (including recognition as an equal partner; access to information, 
participation in decision-making, and reporting relationships to other functions) is significantly lower than other functional areas, such as Research and Development, Marketing, and Engineering. Similarly, Carr \& Smeltzer (1997) conceive the purchasing status as: the strategic role of purchasing, the CPO gaining high visibility with the $\mathrm{CEO} /$ President, and the purchasing function being viewed as equal to other functions by the CEO/President. The authors also demonstrate that the status is an important driver of strategic purchasing (i.e., the long-term planning, implementing, evaluating, and controlling purchasing activities). Maltz \& Ellram (1999) find mixed evidence about the purchasing specialists' influence over corporate-level strategic issues, such as major outsourcing and make-or-buy decisions. Finally, Cousins et al. (2006) confirm that the purchasing function status depends upon the top management support. Not only does top management play an important role in influencing an organisation's attitude toward purchasing, it can also devote resources in terms of time, personnel, and finances toward functional capability improvement. When purchasing is considered to be strategic, it is more likely to be involved in the strategic dialogue of a firm. Other functional areas may also engage with purchasing to seek input and to leverage its expertise.

As a result of previous arguments, we expect that the status acquired by the purchasing function has a positive impact on the implementation of purchasing practices. The literature suggests measuring the status of the purchasing function by looking at its interactions with the other functions, its perception by the top management, and its involvement in the strategic planning process (Moody, 2001; Chen et al., 2004; Cousins et al., 2006), which we refer to as purchasing recognition (see also Table II and III). Therefore, the second research hypothesis is the following:

\section{H2: Purchasing Recognition has a positive effect on the adoption of Purchasing Practices. \\ H2a: $\quad$ Purchasing Recognition has a positive effect on Supplier Development \& Integration. \\ H2b: $\quad$ Purchasing Recognition has a positive effect on Spend Rationalization. \\ H3c: $\quad$ Purchasing Recognition has a positive effect on Sustainable Purchasing}

It may also be noted that the closer the purchasing function is to the CEO of the firm, the more likely it will be involved in the strategic decision-making. For this reason, its hierarchical position in the organisation chart might also be considered a measure of its status within the firm (Mol, 2003; González-Benito, 2010). In other words, we expect that the reporting level of the purchasing function to the CEO leads to greater purchasing practices implementation. As a result, we can introduce the third research hypothesis as follows:

\section{H3: Purchasing Report Level has a positive effect on the adoption of Purchasing Practices.}

H3a: $\quad$ Purchasing Report Level has a positive effect on Supplier Development \& Integration.

H3b: $\quad$ Purchasing Report Level has a positive effect on Spend Rationalization.

H3c: $\quad$ Purchasing Report Level has a positive effect on Sustainable Purchasing 
Figure 1. Research model and hypotheses.

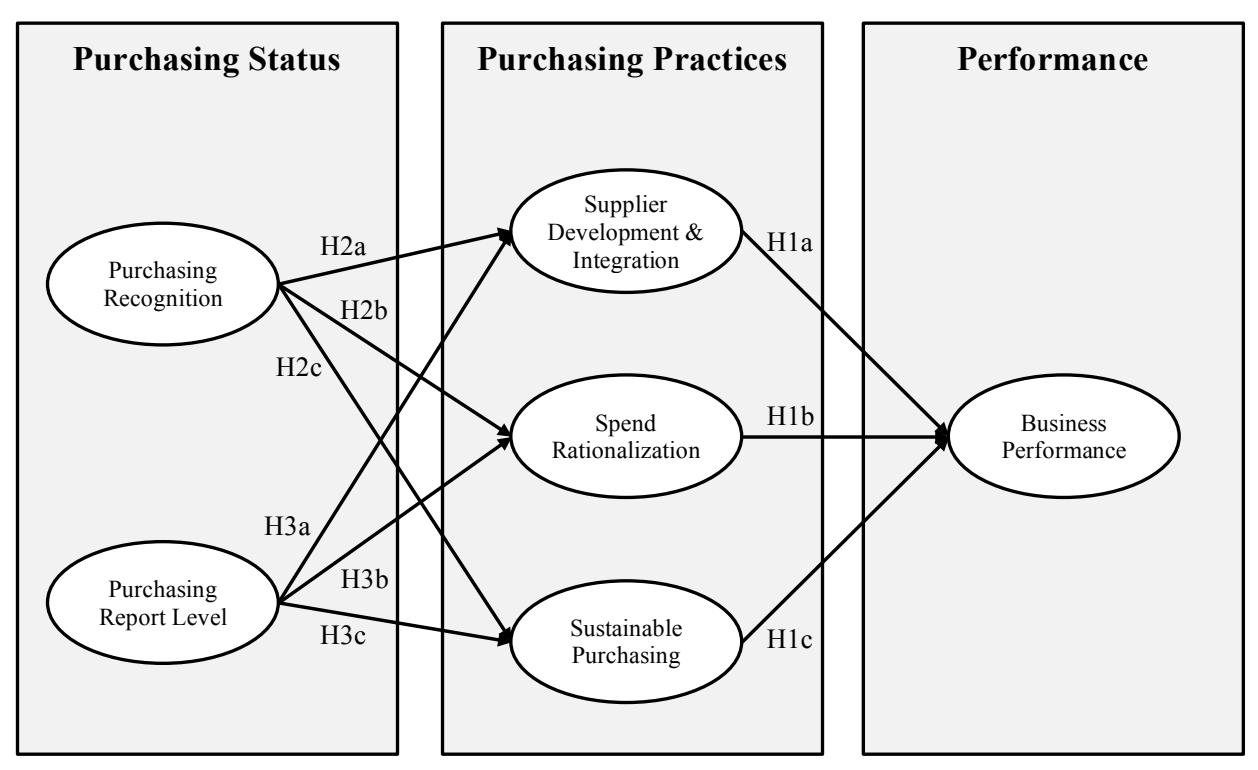




\section{Research methodology}

\subsection{Sample}

To test the research model, we used data collected through IPS, an international survey precisely aiming at investigating purchasing role and purchasing practices within companies. Data were collected during the winter of 2009/2010 from ten different countries (see Table I). According to the suggestions for future research provided by Chen et al. (2004) the targeted companies were of different sizes and from different sectors, both in manufacturing and in service industries. In the sampling procedure, contacts were stratified in terms of countries and industries. The overall sample is made of 681 usable responses. We only excluded responses from the Public Administration and agriculture and mining, as we wanted to focus on secondary and tertiary industries, thus obtaining 653 usable responses.

The survey is based on a questionnaire composed by constructs derived from the literature. The English version of the questionnaire was translated into different languages using the TRAPD (Translation, Review, Adjudication, Pre-testing and Documentation) procedure (Harkness et al., 2002) and subsequently tested by submitting it to a couple of purchasing executives for each country. The final version of the survey tool was uploaded onto the project website and made visible only to respondents selected in the sampling procedure. The Internet survey offers higher levels of accuracy and reduces missing values due to either the respondent or some data entry mistakes (Boyer et al., 2002). Following other similar key informant-based research studies (Cini et al., 1993; Cousins, 2005), the goal was to find the right person within the organisation who was able to respond to all of the questions about the purchasing function, its involvement in the strategic planning process of the company, and to collect data on business performance. For this reason, mostly CPOs, VPs of Purchasing, Purchasing Directors and Purchasing Managers were involved.

To test non-response bias, the final sample was divided into early and late respondents, assuming that late respondents were similar to non-respondents (Armstrong \& Overton, 1977); $t$-tests were conducted with variables that were included in the model, and no significant differences were found between the two groups.

Knoppen et al. $(2010,2011)$ provide a detailed description of the project and check for sample equivalence through multi-group confirmatory factor analysis (CFA). Authors show that, although data were collected in different countries, responses and constructs were consistent and reliable. Thus, the entire database may be used altogether. 
Table I. Sample descriptive statistics.

\begin{tabular}{|c|c|c|}
\hline Descriptive & Frequency & Percentage \\
\hline \multicolumn{3}{|l|}{ Country } \\
\hline Sweden & 143 & 21.9 \\
\hline United Kingdom & 86 & 13.2 \\
\hline Germany & 68 & 10.4 \\
\hline United States & 67 & 10.3 \\
\hline Netherlands & 54 & 8.3 \\
\hline Italy & 53 & 8.1 \\
\hline Canada & 52 & 8.0 \\
\hline Spain & 49 & 7.5 \\
\hline Finland & 41 & 6.3 \\
\hline France & 40 & 6.1 \\
\hline \multicolumn{3}{|l|}{ Sales (mln€) } \\
\hline$<50$ & 199 & 30.5 \\
\hline$<250$ & 171 & 26.2 \\
\hline$<500$ & 68 & 10.4 \\
\hline$<1,000$ & 44 & 6.7 \\
\hline$<10,000$ & 92 & 14.1 \\
\hline$>=10,000$ & 26 & 4.0 \\
\hline Missing & 53 & 8.1 \\
\hline \multicolumn{3}{|l|}{ Sector } \\
\hline Manufacturing & 431 & 66.0 \\
\hline Wholesale and retail trade & 37 & 5.7 \\
\hline Other & 36 & 5.5 \\
\hline Transportation, storage and communication & 34 & 5.2 \\
\hline Construction & 29 & 4.4 \\
\hline Electricity, gas, and water supply & 21 & 3.2 \\
\hline Professional and administrative services & 21 & 3.2 \\
\hline Financial services & 14 & 2.1 \\
\hline Human health and social work activities & 11 & 1.7 \\
\hline Hotels and restaurants & 6 & 0.9 \\
\hline Arts, entertainment and recreation & 6 & 0.9 \\
\hline Missing & 7 & 1.1 \\
\hline \multicolumn{3}{|l|}{ Respondent position } \\
\hline $\mathrm{CPO}, \mathrm{VP}$ of purchasing & 91 & 13.9 \\
\hline Purchasing director & 134 & 20.5 \\
\hline Purchasing manager & 306 & 46.9 \\
\hline Senior, Project buyer & 53 & 8.1 \\
\hline Buyer, Purchasing agent & 33 & 5.1 \\
\hline Other & 35 & 5.4 \\
\hline Missing & 1 & 0.2 \\
\hline Total & 653 & 100 \\
\hline
\end{tabular}




\subsection{Measures}

Hypotheses were tested using the maximum likelihood (ML) estimation method. Most structural equation models (SEM) described in the literature are analysed with this methodology. The hypothesised model was tested statistically in a simultaneous analysis of the entire system of variables to determine the extent to which it is was consistent with the data. Where goodness-of-fit is adequate, the model can be seen as a plausible explanation of postulated interactions between constructs. The research model is analysed and interpreted sequentially: first the assessment of the reliability and validity of the measurement model and secondly the assessment of the structural model (Hulland et al., 1996).

To measure latent variables included in the research framework we considered the extant literature and we operationalized a set of seven constructs, with an addition of two control variables. Table II provides a description of each construct along with the main references, whereas Table III shows the indicators used. In particular, two constructs reflect the components of the purchasing status introduced above, i.e., Purchasing Recognition and Report Level. The former was measured by asking respondents to what extent they agree with a set of nine statements (see Table III), using a 6-point Likert scale (1="totally disagree"; 6="totally agree"). The latter was measured by asking the number of direct-report levels between the CPO and the CEO. Then, three constructs are dedicated to purchasing practices (i.e., Supplier Development \& Integration; Spend Rationalization; and Sustainable Purchasing) asking to what extent the company pursued a series of actions on a 6-point Likert-like scale (1="not at all"; 6="completely"). All indicators are shown in Table III. Finally, we used four indicators to measure the Business Performance, asking respondents to rate their own company in comparison to competitors on a 7-points Likert-like scale (1="far worse"; 6="far better"). In addition to the main constructs included in our research model (see Figure 1), we considered two main control variables: the Market Trend, measured through the rate of decline or growth of demand on a 7-points Likert-like scale (1="extremely decreasing"; 6="extremely increasing"); and the Purchasing Spend, measured as the ratio between purchasing spend and sales. We also tested other common control variables (such as the firm industry and size) which resulted as non significant, therefore we avoid to include them in the final model.

We evaluate the model fit through recommended goodness-of-fit statistics ( $\mathrm{Hu} \&$ Bentler, 1999). Some authors suggest to check for the ratio between chi-square value and degrees of freedom in the model, where cutoffs values ranges from $<2$ to $<5$ depending on the investigator (Byrne, 1989; Kelloway, 1998). Another way to evaluate the fit of a model is to use fit indices that range from 0 to 1 , with values closer to 1 indicating good fit. Hu and Bentler (1999) recommend MLE-based fit indices and also suggest a two-index presentation strategy with, among others, the comparative fit index (CFI), and Gamma hat or root mean square error of approximation (RMSEA). An acceptable threshold for CFI is $>0.95$ whereas RMSEA is supposed to be lower than 0.05. Table III shows the results of the Confirmatory Factor Analysis (CFA). All of the model fit indicators were found to be satisfactory $\left(\chi^{2}=301.901\right.$; d.f. $=187$; RMSEA $=.031$; $\mathrm{CFI}=.981$ ). Reliability measured by the Composite Reliability (CR, Fornell \& Larcker, 1981) was also fully satisfactory (Nunnally, 1994). Additionally, convergent validity was assessed through significant loadings from all scale items on the hypothesized constructs, and through the Average Variance Extracted (AVE, Anderson and Gerbing, 1988): AVE ranges between $45 \%$ and $80 \%$. As an additional test for discriminant validity, we compared the squared correlation (Table IV) between two latent constructs to their average variance extracted (AVE) estimates (Fornell \& Larcker, 1981). 
According to this test the AVE for each construct should be higher than the squared correlation between each pair of constructs. This condition is valid for all the constructs.

Next, we performed some tests to assess common method bias. Given that we relied on a single respondent design, we controlled for common method bias in two ways: through the procedure of the study and through statistical control (Podsakoff et al., 2003). Regarding the survey, the research project was labelled as a broad overview of purchasing management and purchasing practices adoption. Therefore no explicit reference to the intention to test the effect of purchasing status was evident. Thus, respondents' attention was not drawn to the relationships being targeted in this study. Moreover, questions including items and constructs related to each other in the general model were separated in the questionnaire in order to prevent respondents from developing their own theories about possible cause-effect relationships. Furthermore, the questionnaire was carefully created and pretested and respondents were assured of strict confidentiality. As a second mean to ensure against common method bias, we performed Harman's single-factor test (Podsakoff et al., 2003), obtaining a 28.5\% variance associated to a single factor for all constructs considered. Overall, this ensures data analysis is not affected by common method bias.

Table II. Constructs included in the model.

\begin{tabular}{|c|l|l|l|}
\hline Concept & First-order construct & Description & References \\
\hline $\begin{array}{c}\text { Purchasing } \\
\text { Status }\end{array}$ & $\begin{array}{l}\text { Purchasing } \\
\text { Recognition }\end{array}$ & $\begin{array}{l}\text { The actual and formal recognition of } \\
\text { the purchasing department strategic } \\
\text { role within the buying firm }\end{array}$ & $\begin{array}{l}\text { Pearson et al., 1996 } \\
\text { Carr \& Smeltzer, 1997 } \\
\text { Chen et al., 2004 } \\
\text { Cousins et al., 2006 }\end{array}$ \\
\cline { 2 - 5 } & $\begin{array}{l}\text { Purchasing Report } \\
\text { Level } \\
\text { (single measure) }\end{array}$ & $\begin{array}{l}\text { Number of direct-report levels } \\
\text { between the highest-ranking member } \\
\text { of purchasing and the CEO }\end{array}$ & $\begin{array}{l}\text { Mol, 2003 } \\
\text { Gonzàlez-Benito, 2010 }\end{array}$ \\
\hline \multirow{5}{*}{$\begin{array}{c}\text { Purchasing } \\
\text { Practices }\end{array}$} & $\begin{array}{l}\text { Supplier Development } \\
\text { \& Integration }\end{array}$ & $\begin{array}{l}\text { Purchasing practices that are mostly } \\
\text { related to upstream initiatives } \\
\text { involving the supply market, such as } \\
\text { collaboration with suppliers and } \\
\text { suppliers' development }\end{array}$ & $\begin{array}{l}\text { Krause \& Ellram, 1997 } \\
\text { Earasimhan \& Das, 2011 } \\
\text { Ellram et al., 2002 }\end{array}$ \\
\cline { 2 - 5 } Cousins, 2005
\end{tabular}


Table III. Resulting constructs operationalization.

\begin{tabular}{|c|c|c|c|c|}
\hline $\begin{array}{l}\text { First-order } \\
\text { construct }\end{array}$ & Indicators & Loading & $\mathbf{C R}$ & AVE \\
\hline \multirow{9}{*}{$\begin{array}{l}\text { Purchasing } \\
\text { Recognition }\end{array}$} & $\begin{array}{l}\text { Top management is supportive of efforts to improve the } \\
\text { purchasing department }\end{array}$ & 0.565 & \multirow{9}{*}{0.880} & \multirow{9}{*}{0.452} \\
\hline & $\begin{array}{l}\text { Purchasing' s views are considered important by most top } \\
\text { managers }\end{array}$ & 0.664 & & \\
\hline & $\begin{array}{l}\text { Purchasing is recognised as an equal partner with other functions } \\
\text { of the top management team }\end{array}$ & 0.671 & & \\
\hline & $\begin{array}{l}\text { Purchasing recommends and initiates changes in products/services } \\
\text { based on supply market analysis }\end{array}$ & 0.616 & & \\
\hline & Purchasing actively participates in new product/service design & 0.625 & & \\
\hline & $\begin{array}{l}\text { Purchasing actively participates in organization-wide process } \\
\text { improvement }\end{array}$ & 0.682 & & \\
\hline & Purchasing is included in the firm's strategic planning process & 0.793 & & \\
\hline & $\begin{array}{l}\text { Purchasing performance is measured in terms of its contributions } \\
\text { to the firm's strategic objectives }\end{array}$ & 0.748 & & \\
\hline & $\begin{array}{l}\text { Purchasing's focus is on longer term issues that involve risk and } \\
\text { uncertainty }\end{array}$ & 0.657 & & \\
\hline \multirow{3}{*}{$\begin{array}{l}\text { Supplier } \\
\text { Development } \\
\text { \& Integration }\end{array}$} & Technological collaboration with suppliers & 0.695 & \multirow{3}{*}{0.759} & \multirow{3}{*}{0.514} \\
\hline & Operational collaboration with suppliers & 0.665 & & \\
\hline & Supplier development & 0.785 & & \\
\hline \multirow{3}{*}{$\begin{array}{l}\text { Spend } \\
\text { Rationalization }\end{array}$} & Centralization of purchasing decisions & 0.551 & \multirow{3}{*}{0.713} & \multirow{3}{*}{0.458} \\
\hline & Supply base optimization & 0.780 & & \\
\hline & Developing a portfolio approach & 0.680 & & \\
\hline \multirow{2}{*}{$\begin{array}{l}\text { Sustainable } \\
\text { Purchasing }\end{array}$} & Environmental sustainability programs & 0.850 & \multirow{2}{*}{0.888} & \multirow{2}{*}{0.798} \\
\hline & Social sustainability programs & 0.935 & & \\
\hline \multirow{4}{*}{$\begin{array}{l}\text { Business } \\
\text { Performance }\end{array}$} & Number of new products/services introduced into the market & 0.588 & \multirow{4}{*}{0.767} & \multirow{4}{*}{0.456} \\
\hline & ROI & 0.727 & & \\
\hline & Net profit & 0.561 & & \\
\hline & Sales growth & 0.797 & & \\
\hline
\end{tabular}

Table IV. Correlation matrix.

\begin{tabular}{lcccccc}
\hline \multicolumn{1}{c}{ Variables } & 1 & 2 & 3 & 4 & 5 & 6 \\
\hline 1. Purchasing Recognition & 1 & & & & & \\
2. Purchasing Report Level & 0.08 & 1 & & & & \\
3. Supplier Development \& Integration & $0.39^{* * *}$ & 0.07 & 1 & & & \\
4. Spend Rationalization & $0.45^{* * *}$ & 0.00 & $0.66^{* * *}$ & 1 & & \\
5. Sustainable Purchasing & $0.31^{* * *}$ & $-0.11^{* *}$ & $0.44^{* * *}$ & $0.39^{* * *}$ & 1 & \\
6. Business Performance & $0.14^{* *}$ & 0.01 & $0.15^{* *}$ & $0.20^{* * *}$ & 0.05 & 1 \\
\hline
\end{tabular}

\footnotetext{
$* * * \mathrm{p}<.001, * * \mathrm{p}<.01, * \mathrm{p}<.05$
} 


\section{Data analysis}

The postulated path model produced a sufficient fit to the data $\left(\chi^{2}=526.781\right.$; d.f. $=234$; RMSEA=.044; NFI=.916; RFI=.892; IFI=.952; CFI=.951). Table V shows the results of the hypotheses testing. Spend rationalization has a positive and significant relation with business performance, thus supporting H1b. On the contrary, Supplier Development \& Integration and Sustainable Purchasing do not affect business performance, thus rejecting $\mathrm{H} 1 \mathrm{a}$ and H1c. Moreover, the structural model shows a positive and highly significant relation between Purchasing Recognition and all three purchasing practices, thus supporting H2. On the contrary, the Report Level is negatively related to Sustainable Purchasing and not related to Supplier Development \& Integration and Spend Rationalization, thus rejecting H3.

Table V. Resulting structural model.

\begin{tabular}{lccc}
\hline \multicolumn{1}{c}{ Path } & $\begin{array}{c}\text { Structural path } \\
\text { coefficient }\end{array}$ & $\begin{array}{c}\text { Standardised } \\
\text { effects }\end{array}$ & Conclusion \\
\hline Supplier Devel. \& Int. $\rightarrow$ Business Performance & n.s. & n.s. & Reject H1a \\
Rationalization $\rightarrow$ Business Performance & $.152^{* * *}$ & $.182^{* * *}$ & Fail to reject H1b \\
Sustainable Purchasing $\rightarrow$ Business Performance & n.s. & n.s. & Reject H1c \\
Purchasing spend $\rightarrow$ Business Performance & n.s. & n.s. & $.309^{* * *}$ \\
Market trend $\rightarrow$ Business Performance & $.198^{* * *}$ & $.435^{* * *}$ & Fail to reject H2a \\
Purchasing Recognition $\rightarrow$ Supplier Devel. \& Int. & $.556^{* * *}$ & $.497 * * *$ & Fail to reject H2b \\
Purchasing Recognition $\rightarrow$ Spend Rationalization & $.640^{* * *}$ & $.335^{* * *}$ & Fail to reject H2c \\
Purchasing Recognition $\rightarrow$ Sustainable Purchasing & $.574^{* * *}$ & n.s. & Reject H3a \\
Report Level $\rightarrow$ Supplier Devel. \& Int. & n.s. & n.s. & Reject H3b \\
Report Level $\rightarrow$ Spend Rationalization & n.s. & $-.132 * * *$ & Reject H3c \\
Report Level $\rightarrow$ Sustainable Purchasing & & &
\end{tabular}

\section{Discussion and results interpretation}

Our first research hypothesis (H1) assumes a positive relationship between a set of three purchasing practices and the overall Business Performance. However, results show that only Spend Rationalization has a positive effect on Business Performance (thus supporting $\mathrm{H} 1 \mathrm{~b}$ ). A first observation that might be drawn is that the purchasing function creates value for the company by carefully analysing the spending, the supply base and developing appropriate category strategies. On the one hand, this might be the result of an efficiency-driven strategy, aiming at purchase volume consolidation (either through centralization or supply base reduction) and consequent price reductions from suppliers. This represents the classical way purchasing improves the company profit by lowering the costs. On the other hand, our result can also point to an effectiveness-driven strategy: by selecting the right suppliers and by establishing specific strategies for different sets of purchasing categories, firms might be able to increase the level of quality, service level, or innovation from suppliers, thus improving internal operations and - possibly - the end customer satisfaction.

On the contrary, Supplier Development \& Integration and Sustainable Purchasing practices do not affect Business Performance in our sample, thus leading to reject H1a and H1c. This result is not consistent with previous studies arguing that the relationship with suppliers and reverse marketing initiatives contributes to value creation (Cousins, 
2005; Wynstra et al., 2010) and that firms might get economic benefits by being sustainable (Rao \& Holt, 2005). A possible interpretation of this result might be related to the level of analysis: both Supplier Development \& Integration and Sustainable Purchasing are likely to occur for specific categories of purchases, and not necessarily within the whole supply base. As this study considers business performance overall, the effects of practices at the category level might not be captured by the model, in case they are not sufficiently diffused across the purchasing portfolio. Another possible interpretation relates to the time lag between those practices and the actual impact on business performance. While Spend Rationalization is relatively quick to implement and therefore is likely to have an impact in the short run, Supplier Development \& Integration and Sustainable Purchasing do require more time in order to have positive effects in the long run. Furthermore, while the former does not require large investments, the latters carry on several costs connected to their implementation, which could ultimately counterbalance the benefits in the short term. Finally, a wide debate is on-going in terms of sustainability effects on functional and business performance, including the investigation of possible trade-off effects (Wu \& Pagell, 2011). Such a matter is out of the scope of our study, but further research might clarify which sustainable purchasing practices (and under which conditions) might enhance the performance trade-off .

The second important result of this study is related to our hypotheses on the purchasing status in the company ( $\mathrm{H} 2$ and $\mathrm{H} 3$ ). As expected, Purchasing Recognition is crucial for the development of all purchasing practices considered. We interpret this result by arguing that the top management support and the purchasing function participation into strategic processes facilitate the adoption and deployment of purchasing practices, at least in terms of Supplier Development \& Integration, Spend Rationalization and Sustainable Purchasing. In other words, if the purchasing employees are recognized as peers and are trusted by other departments, that creates a fertile environment for an effective implementation of purchasing practices. Interestingly, Purchasing Recognition does not necessarily come with formal authority. As a matter of fact, results show that a purely formal status provided by the Report Level does not have any significant effect on the adoption of Supplier development \& Integration or Spend Rationalization practices. Even more, the Report Level negatively affects the adoption of Sustainable Purchasing practices. It seems that the more the CPO gets close to the CEO, the less sustainability becomes a priority. This result might be partially explained considering the time of data collection, which followed the 20072008 financial crisis and likely determined a greater emphasis on classical financial performance. Nowadays, a more mature and comprehensive view of sustainability has long shown its potential to foster the creation of long-term competitive advantage.

Considering the control variables (i.e., Market Trend and Purchasing Spend), only the former is significantly linked to performance. Not surprisingly, this means that a positive or negative economic cycle will show its effects on the Business Performance. This result further confirms the significance of the other predictor (i.e., Spend Rationalization).

Overall, we can comment this second result by observing that the actual recognition of the purchasing function is much more important than its formal position within the organisation chart in order to foster the adoption of purchasing practices and contribute to the overall business performance. 


\section{Conclusions, limitations and future developments}

The study presented in this paper contributes to developing the long-lasting debate in the literature and in practice about the role of the purchasing function within companies. According to some authors, some companies' purchasing activities are clerical in their nature and cannot contribute to value creation; according to others, purchasing activities are strategic and create value for the company. Moreover, few studies acknowledge the effect of the purchasing status on the implementation of practices and, consequently, on business performance. Thanks to an international and cross-sectorial survey, we provide measures for defining the purchasing status within an organization (i.e., Purchasing Recognition and Report Level), assessing its impact on the adoption of key purchasing practices (i.e., Supplier Development \& Integration, Spend Rationalisation, and Sustainable Purchasing) and ultimately on Business Performance. In particular, we show that Spend Rationalization is the only practice significantly improving Business Performance, at least in the short term. Even more importantly, our results suggest that the actual recognition of the purchasing function by top management and other departments is a crucial driver of all purchasing practices, whereas the pure formal authority provided by a high position in the organization chart does not have a significant impact on purchasing practices and it might become harmful when considering Sustainable Purchasing.

Besides the aforementioned contributions to the research debate, we believe our results have clear implications for the purchasing profession. First of all, our results supports purchasing professionals in the resource allocation on specific practices, emphasizing that the definition of appropriate category strategies and the right balance in terms of centralization and supply base rationalization do contribute to value creation at the corporate level. Of course, this does not mean abandoning clerical activities that must be carried on efficiently and effectively. Indeed, managing clerical activities in the right way is a prerequisite for dedicating time and effort to more value added practices. Secondly, we are able to show that whenever the purchasing function is considered a Branking unit, this attitude will greatly obstacle the effective implementation of purchasing practice and - consequently - the potential contribution to business performance. This is especially true when considering the informal recognition of top managers and other departments rather than the formal position within the organization.

In the end, it is worth addressing some limitations of this work and providing some suggestions for future developments. First of all, this paper considers some representative purchasing practices derived from the literature. Such list is not exhaustive, and a more comprehensive assessment of practices might be performed. Similarly, we measure the business performance with one single construct on a crosssectional sample. Further research might explore the effect of purchasing status and practices on multiple performance dimensions and on a longitudinal dataset. Finally, testing the results across different countries was out of the scope of this study. However, it might be interesting to develop the theoretical debate and provide empirical evidence about the effect of different national or regional cultures on the relationships targeted by our model. 


\section{References}

Anderson, J.C., Gerbing, D.W., 1988. Structural Equation Modeling in Practice: A Review and Recommended Two-Step Approach. Psychological Bulletin 103(3), 411-423.

Armstrong J.S., Overton T.S., 1977. Estimating Nonresponse Bias in Mail Surveys. Journal of Marketing Research 14, 396-402.

Arnold U., 1999. Organization of global sourcing: ways towards an optimal degree of centralization. European Journal of Purchasing \& Supply Management 5(3-4), 167-174.

Azadegan A. \& Dooley K.J., 2010. Supplier innovativeness, organizational learning styles and manufacturer performance: An empirical assessment. Journal of Operations Management 28(6), 488505.

Berger P., Gerstenfeldb A. \& Zeng A.Z., 2004. How many suppliers are best? A decision-analysis approach. Omega 32(1), 9-15.

Bernardes E., Zsidisin G., 2008. An examination of strategic supply management benefits and performance implications. Journal of Purchasing and Supply Management 14(4), 209-219.

Blome, C., Hollos, D. \& Paulraj, A., 2014. Green procurement and green supplier development: antecedents and effects on supplier performance. International Journal of Production Research, 52(1), 32-49.

Bowen F.E., Cousins P.D., Lamming R.C., Farukt A. C., 2001. The role of supply management capabilities in green supply. Production and Operations Management 10(2), 174-189.

Boyer K.K., Olson J.R., Calantone J.R., 2002. Print versus electronic surveys: a comparison of two data collection methodologies. Journal of Operations Management 20, 357-373.

Brewer, B., Wallin, C. \& Ashenbaum, B., 2014. Outsourcing the procurement function_Do actions and results align with theory? Journal of Purchasing and Supply Management, 20(3), 186-194.

Burt D.N., Soukup W.R., 1985. Purchasing's Role in New Product Development. Harvard Business Review (September), 90-97.

Buyukozkan G., Arsenyan J., 2012. Collaborative product development: a literature overview. Production Planning \& Control, 23(1), 47-66.

Byrne, B.M., 1989. A primer of LISREL: basic applications and programming for confirmatory factor analytic models. New York: Springer-Verlag.

Caniato, F., Longoni, A. \& Moretto, A., 2012. Effective eProcurement implementation process. Production Planning \& Control, 23(12), 935-949.

Caniato, F., Luzzini, D. \& Ronchi, S., 2014. Purchasing performance management systems: an empirical investigation. Production Planning \& Control, 25(7), 616-635.

Carr A.S., Pearson J.N., 1999. Strategically managed buyer-supplier relationships and performance outcomes. Journal of Operations Management 17(5), 497-519.

Carr A.S., Pearson J.N., 2002. The impact of purchasing and supplier involvement on strategic purchasing and its impact on firm's performance. International Journal of Operations \& Production Management 22(9), 1032-1053.

Carr A.S., Smeltzer L.R., 1997. An empirically based operational definition of strategic purchasing. European Journal of Purchasing and Supply Management 3(4), 199-207.

Carr A.S., Smeltzer L.R., 2000. An empirical study of the relationships among purchasing skills and strategic purchasing, financial performance, and supplier responsiveness. The Journal of Supply Chain Management (Summer), 40-54.

Carter C.R., 2004. Purchasing and Social Responsibility: A Replication and Extension. The Journal of Supply Chain Management 40(4), 4-16.

Carter J.R., Narasimhan R., 1996. Is Purchasing Really Strategic? The Journal of Supply Chain Management 32(1), 20-28.

Chen I., Paulraj A., Lado, A.A., 2004. Strategic purchasing, supply management, and firm performance. Journal of Operations Management 22, 505-523.

Cini M., Moreland R., Levine J., 1993. Group staffing levels and responses to prospective and new group members. Journal of Personality and Social Psychology 65(4), 723-734.

Cousins P.D., 2005. The alignment of appropriate firm and supply strategies for competitive advantage. International Journal of Operations \& Production Management 25(5), 403-428.

Cousins P.D., Lawson B., Squire B., 2006. An empirical taxonomy of purchasing functions. International Journal of Operations \& Production Management 26(7), 775-794.

Cox A., Lamming R.C., 1997. Managing supply in the firm of the future. European Journal of Purchasing \& Supply Management 3(2), 53-62. 
Day M., Lichtenstein S., 2006. Strategic supply management: the relationship between supply management practices, strategic orientation and their impact on organizational performance. Journal of Purchasing and Supply Management 12, 313-321.

De Toni A., Nassimbeni G., 2000. Just-in-time purchasing: An empirical study of operational practices, supplier development and performance. Omega 28(6), 631-651.

Ellram L. M., Zsidisin G.A., Siferd S.P., Stanley M.J., 2002. The impact of purchasing and supply management activities on corporate success. The Journal of Supply Chain Management (Winter), 417.

Ellram L.M., Billington C., 2001. Purchasing leverage considerations in the outsourcing decision. European Journal of Purchasing \& Supply Management 7(1), 15-27.

Fornell, C., Larcker, D.F., 1981. Structural Equation Models with Unobservable Variables and Measurement Error: Algebra and Statistics. Journal of Marketing Research 18(3), 382-388.

Gelderman C.J., van Weele A.J., 2005. Purchasing Portfolio Models: A Critique and Update. The Journal of Supply Chain Management 41(3), 19-28.

González-Benito J., 2007. A theory of purchasing's contribution to business performance. Journal of Operations Management 25(4), 901-917.

González-Benito J., 2010. Supply strategy and business performance: An analysis based on the relative importance assigned to generic competitive objectives. International Journal of Operations \& Production Management 30(8), 774-797.

Handfield R.B., 1994. US Global Sourcing: Patterns of Development. International Journal of Operations and Production Management 14(6), 40-51.

Harkness J.A., Vijver F.J., Mohler, P.P., 2002. Cross-Cultural Survey Methods (Wiley Series in Survey Methodology), Wiley-Interscience.

Hartmann E., Kerkfeld D., Henke M., 2012. Top and bottom line relevance of purchasing and supply management. Journal of Purchasing and Supply Management 18, 22-34.

Hu, L., Bentler, P.M., 1999. Cutoff criteria for fit indexes in covariance structure analysis: conventional criteria versus new alternatives. Structural Equation Modeling 1999, 6(1), 1-55.

Hulland, J., Chow, Y.H. \& Lam, S., 1996. Use of causal models in marketing research: A review. International Journal of Research in Marketing, 13(2), 181-197.

Humphreys P., Cadden T., Wen-Li L., McHugh M., 2011. An investigation into supplier development activities and their influence on performance in the Chinese electronics industry. Production Planning \& Control, 22(2), 137-156.

Johnson P.F., Leenders M.R. \& Fearon H.E., 1998. Evolving Roles and Responsibilities of Purchasing Organizations. International Journal of Purchasing and Materials Management (January), 2-11.

Kelloway, E.K., 1998. Using LISREL for structural equation modeling: a re- searcher's guide. Thousand Oaks: Sage Publications.

Knoppen D. et al., 2010. Analysis of equivalence among sub-samples: preliminary results of the International Purchasing Survey. In Proceedings of the XVII EurOMA conference, Porto, 1-10.

Knoppen, D. \& Sáenz, M.J., 2014. Purchasing: Can we bridge the gap between strategy and daily reality? Business Horizons, 58(1), 123-133.

Knoppen, D. et al., 2011. Pooling Survey Data in the Operations and Supply Management Literature: A Review and Illustration of Equivalence Tests. In Proceedings of the XX IPSERA conference, Maastricht, 1-10.

Kraljic, P., 1983. Purchasing Must Become Supply Management. Harvard Business Review 61(5), 109117.

Krause D., Pagell, M., S., C., 2001. Toward a measure of competitive priorities for purchasing. Journal of Operations Management 19(4), 497-512.

Krause D.R., Ellram, L.M., 1997. Success factors in supplier development. International Journal of Physical Distribution \& Logistics Management 27(1), 39-52.

Luzzini, D., Amann, M., Caniato, F., Essig, M., Ronchi, S., 2015. The path of innovation: purchasing and supplier involvement into new product development. Industrial Marketing Management, 47(C), 109120.

Maltz A., Ellram L., 1999. Outsourcing Supply Management. The Journal of Supply Chain Management (May), 4-17.

Marshall, D. et al., 2015. Environmental and social supply chain management sustainability practices: construct development and measurement. Production Planning \& Control, 26(8), 673-690.

McGrath R.G., Macmillan I.C., Tushman M.L., 1992. The role of executive team actions in shaping dominant designs: Towards the strategic shaping of technological progress. Strategic Management Journal 13(S2), 137-161. 
McKinsey (2014), Sustainability's strategic worth: McKinsey Global Survey results, McKinsey Report, July.

Mehra S., Inman A., 2004. Purchasing management and business competitiveness in the coming decade. Production Planning \& Control, 15(7), 710-718.

Mintzberg H., 1992. The strategy process. In: The strategy process: concepts and context. Ed.H. Mintzberg \& J.B. Quinn. Englewood Cliffs, NJ: Prentice Hall.

Mol M., 2003. Purchasing's strategic relevance. Journal of Purchasing and Supply Management 9, 43-50.

Moody P.E., 2001. Strategic Purchasing Remains an Oxymoron. MIT Sloan Management Review, 18.

Najmi A., Makui A., 2012. A conceptual model for measuring supply chain's performance. Production Plannind \& Control, 23(9), 694-706.

Narasimhan R., Das, A., 2001. The impact of purchasing integration and practices on manufacturing performance. Journal of Operations Management, 19, 593-609.

Nelson D., Moody P.E., Stegner J., 2001. The purchasing machine. The Free Press, New York.

Nollet J., Beaulieu M., 2003. The development of group purchasing: an empirical study in the healthcare sector. Journal of Purchasing and Supply Managemen, 9(1), 3-10.

Nollet J., Beaulieu M., 2005. Should an organisation join a purchasing group? Supply Chain Management: An International Journal 10(1), 11-17.

Norusis M., 1993. SPSS for Windows. Professional statistics. Release 6.0. SPSS Inc., Chicago, Illinois.

Nunnally J.C., 1994. Psychometric Theorym 3rd ed. McGraw-Hill, New York.

Ogden J., Rossetti C., Hendrick T., 2007. An exploratory cross-country comparison of strategic purchasing. Journal of Purchasing and Supply Management 13(1), 2-16.

Oke A., Kach A., 2012. Linking sourcing and collaborative strategies to financial performance: the role of operational innovation. Journal of Purchasing and Supply Management 18, 46-59.

Oltra M.J., Flor M.L., 2010. The moderating effect of business strategy on the relationship between operations strategy and firms' results. International Journal of Operations \& Production Management 30(6), 612-638.

Paulraj A., Chen I. \& Flynn, J., 2006. Levels of strategic purchasing: Impact on supply integration and performance. Journal of Purchasing and Supply Management 12(3), 107-122.

Pearson J., Gritzmacher K., 1990. Integrating purchasing into strategic management. Long Range Planning 23(3), 91-99.

Pearson J.N., Ellram, L.M., Carter, C.R., 1996. Status and Recognition of the Purchasing Function in the Electronics Industry. The Journal of Supply Chain Management 32(2), 30-36.

Perkins D., Gunasekaran A., 1998. Improving the effectiveness of purchasing in a small company: A case study. Production Planning \& Control, 9(6), 611-618.

Podsakoff, P., MacKenzie, S., Lee, J., Podsakoff, N. (2003), Common method biases in behavioural research: A critical review of the literature and recommended remedies, Journal of Applied Psychology 88, 879-903.

Porter M., 1985. Competitive advantage, New York: Free Press.

Puschmann T., Alt R., 2005. Successful use of e-procurement in supply chains. Supply Chain Management: An International Journal 10(2), 122-133.

Ramsay J., 2001a. Purchasing's strategic irrelevance. European Journal of Purchasing \& Supply Management 7, 257-263.

Ramsay J., 2001b. The Resource Based Perspective, rents, and purchasing's contribution to sustainable competitive advantage. The Journal of Supply Chain Management (Summer), 38-47.

Ramsay J., Croom S., 2008. The impact of evolutionary and developmental metaphors on Purchasing and Supply Management: A critique. Journal of Purchasing and Supply Management 14, 192-204.

Rao, P., Holt, D., 2005. Do green supply chains lead to competitiveness and economic performance? International Journal of Operations \& Production Management 25(9), 898-916.

Rozemeijer F.A., 2008. Purchasing myopia revisited again? Journal of Purchasing and Supply Management 14, 205-207.

Rozemeijer F.A., van Weele A., Weggeman M., 2003. Creating corporate advantage through purchasing: toward a contingency model. The Journal of Supply Chain Management (Winter), 4-13.

Schiele H., 2007. Supply-management maturity, cost savings and purchasing absorptive capacity: testing the procurement-performance link. Journal of Purchasing and Supply Management 13, 274-293.

Thompson M., 1996. Insights from industry Effective purchasing strategy : the untapped source of competitiveness. Supply Chain Management 1(3), 6-8.

Trent R.J., Monczka, R.M., 1998. Purchasing and Supply Management: Trends and Changes Throughout the 1990s. The Journal of Supply Chain Management 34(4), 2-11.

Vining A., Globerman, S., 1999. A Conceptual framework for Understanding the Outsourcing Decision. European Management Journal 17(6), 645-654. 
Wagner S.M., 2006. A firm's responses to deficient suppliers and competitive advantage. Journal of Business Research 59(6), 686-695.

Walker H. Phillips W., 2009. Sustainable Procurement: Emerging Issues. International Journal of Procurement Management 2(1), 41-61.

Watts C.A., Kim, K.Y., Hahn, C.K., 1995. Linking Purchasing to Corporate Competitive Strategy. The Journal of Supply Chain Management 31(2), 2-8.

Wu, Z. \& Pagell, M., 2011. Balancing priorities: Decision-making in sustainable supply chain management. Journal of Operations Management, 29(6), 577-590.

Wynstra F., von Corswant, F., Wetzels, M., 2010. In Chains? An Empirical Study of Antecedents of Supplier Product Development Activity in the Automotive Industry. Journal of Product Innovation Management 27, 625-639.

Yu H., Zeng A., Zhao L., 2009. Single or dual sourcing: decision-making in the presence of supply chain disruption risks. Omega 37(4), 788-800.

Zheng J., Knight L., Harland C., Humby S., James K., 2007. An analysis of research into the future of purchasing and supply management. Journal of Purchasing and Supply Management 13(1), 69-83.

Zimmermann, F. \& Foerstl, K., 2014. A Meta-Analysis of the "Purchasing and Supply Management Practice-Performance Link.” Journal of Supply Chain Management. 